\title{
O sposobach wznoszenia zamków krzyżackich na przykładzie warowni w Działdowie
}

Działdowo znajduje się obecnie w południowej części województwa warmińsko-mazurskiego. Dawniej ziemie te nazywane były Sasinią. W czasach państwa zakonu krzyżackiego miasto to było jednym z najbliższych Mazowsza miast pruskich. $Z$ tego względu zamek i późniejsze miasto miały duże znaczenie strategiczne. W niniejszym artykule chciałbym omówić dzieje budowlane zamku oraz technikę i organizację wznoszenia tej warowni, w świetle badań terenowych.

\section{Cztery gotyckie fazy zamku w Działdowie}

W przypadku zachowanego do dnia dzisiejszego założenia murowanego, które powstało na rzucie kwadratu o boku $46 \mathrm{~m}$, wyróżniono cztery fazy gotyckie budowy zamku' ${ }^{1}$. W pierwszej fazie wzniesiono budynek główny, który był niższy od obecnego o kondygnację spichrzową, z rzędem strzelnic pod dachem.

$\mathrm{W}$ drugiej fazie powstały mury obwodowe, baszta przybramna, brama wjazdowa, baszta północna mur zewnętrzny północno-zachodni, ogradzający parcham i mury przedzamcza. Przy północno-zachodnim murze powstał łącznik między budynkiem głównym a basztą przybramną, przebiegający od drugiej kondygnacji wzwyż - być może w formie drewnianego budynku wspartego na słupach ${ }^{2}$. Potwierdzeniem powstania budynku bramnego, równolegle z murami kurtynowymi, jest przewiązanie ich fundamentów ${ }^{3}$. Baszta przybramna, znajdująca się z prawej strony przejazdu bramnego, powstała na rzucie kwadratu o boku 13,5 m i ma dwie kondygnacje piwnic. Dolna posiadała sklepienia, górna strop drewniany. Niższa kondygnacja pełniła najpewniej

1 W. Galicki, Działdowo. Zamek krzyżacki. Badania architektoniczne, Warszawa 1958/1959, mps. w archiwum Wojewódzkiego Urzędu Ochrony Zabytków w Olsztynie [dalej: WUOZO].

2 Ibidem, s. 2.

3 M. Milewska, Sprawozdanie z badań archeologicznych prowadzonych na zamku w Działdowie w latach 1981-1989, Warszawa 1990, s. 11, mps. WUOZO. 
funkcję pomieszczenia więziennego. Świadczą o tym doły kloaczne wykute w wylewce, wyłożone kawałkami cegieł ${ }^{4}$. Baszta północna została wysunięta na północ, skośnie w stosunku do czworoboku zamkowego. Jej podstawa jest kwadratowa, o ściętych narożach, górą przechodzi w ośmiobok.

W trzeciej fazie dobudowano dwa murowane skrzydła: północno-wschodnie i południowo-zachodnie. W tej fazie we wszystkich salach parteru Domu Dużego założono sklepienia krzyżowo-żebrowe z gurtami, a w salach skrajnych wsparte na filarach. Nie liczono się przy tym z pierwotnymi podziałami ścian. Wsporniki sklepienne zostały oparte w kilku miejscach o zamurowane pierwotne otwory okienne i drzwiowe ${ }^{5}$. W środkowej sali, w jej północnej części wydzielono niewielkie pomieszczenie dla hypocaustum ${ }^{6}$.

Skrzydło północno-wschodnie zostało dobudowane, nie licząc się z istniejącym podziałem elewacji dziedzińca budynku głównego. Mury nowego skrzydła dostawiono do pierwotnych otworów wejściowych elewacji budynku głównego, które zostały wówczas zamurowane ${ }^{7}$. Skrzydło północno-wschodnie nie było podpiwniczone. Pierwotnie w najniższej kondygnacji znajdowały się dwa pomieszczenia różnej wielkości. W pomieszczeniu północnym znajdowały się dwa filary. Nieco później dostawiono do tego skrzydła jeszcze jedno niewielkie pomieszczenie $(2,5 \times 3,2 \mathrm{~m})^{8}$.

$\mathrm{Z}$ układu stratygraficznego wynika, że skrzydło północno-wschodnie zostało wzniesione niewiele później niż Dom Duży. W 1348 r. wzmiankowany jest już urzędnik w Działdowie. Jeśli przyjmiemy, że Dom Duży wówczas już stał, to można przypuszczać, że skrzydło północno-wschodnie powstało po najazdach litewskich w $1376 \mathrm{r}$. Za takim datowaniem przemawia znalezisko kwartnika krzyżackiego w warstwie spalenizny, którą można łączyć ze zniszczeniami spowodowanymi najazdem litewskim 9 . Monety te pojawiły się w obiegu w latach 1360-1380. Izabela Galicka wiąże tę rozbudowę z powiększeniem załogi zamkowej w wyniku ustanowienia w Działdowie wójtostwa i datuje ją na rok $1383^{10}$. Oczywiście należy zaznaczyć, że jeżeli przyjmiemy zaproponowane przez nią datowanie, to należy tutaj mówić o rozbudowie od roku 1383.

$4 \quad$ Ibidem, s. 12.

5 I. Galicka, Działdowo. Zamek krzyżacki, Warszawa 1958/1959, mps. WUOZO.

$6 \quad$ W. Galicki, Działdowo. Zamek krzyżacki..., s. 3.

7 I. Galicka, Działdowo. Zamek krzyżacki, s. 44.

8 K. Blusiewicz, Sprawozdanie z badań archeologicznych przeprowadzonych na zamku w Działdowie w 2008 r., s. 2-3, mps. WUOZO.

$9 \quad$ M. Milewska, Sprawozdanie z badań..., s. 8.

10 I. Galicka, Działdowo. Zamek krzyżacki, s. 43. 
W ostatniej średniowiecznej fazie podwyższono budynek główny o kondygnację spichlerzową. Analogicznie postąpiono ze skrzydłami północno-wschodnim i południowo-zachodnim. Galicka polemizuje z Ernstem Gallem co do datowania owej rozbudowy. Jej zdaniem miało to miejsce wcześniej niż sugerował niemiecki badacz, a mianowicie między 1383 a 1410 r. $^{11}$ Był to okres względnego spokoju, a zamek w swoim strategicznym położeniu nie mógł być rozbudowywany w czasie szczególnego napięcia wojennego. Datowanie to, jej zdaniem, potwierdza również analiza stylowa szczytów, sklepień, a także wsporników o motywie maski ludzkiej. Łączyłoby się to z uwagą Mieczysława Haftki, że w 1407 r. przeznaczono na roboty murarskie 1397 grzywien $^{12}$.

Istnienie wcześniejszej warowni na miejscu działdowskiego zamku, która miałaby funkcjonować już na początku XIV w., wciąż nie jest pewne. Co prawda Aleksander Gardawski natrafił na ślady drewnianej budowli i przyjął wstępnie, że budynek ten mógł stanowić pierwszą fazę zamku krzyżackiego ${ }^{13}$, jednak został on uchwycony w tak niewielkim fragmencie, że istnienie tego pierwotnego założenia wciąż pozostaje hipotezą.

\section{Materiały budowlane}

O wzmiankach i zachowanych śladach cegielni wiemy głównie z okresu ostatnich dziesięcioleci XIV i początku XVw. Cegielnie powstawały w związku z poszczególnymi inwestycjami, ale również istniały od nich niezależnie. Pierwsze z nich wznoszono na czas realizacji aktualnie wznoszonej budowli, a po jej zakończeniu likwidowano. Drugie nastawione były na stałą produkcję dla szerszego grona odbiorców. Patrząc na analogie z innych regionów Europy, można przypuszczać, że mniejsze wyrabiały cegłę konstrukcyjną, natomiast cegły profilowane sprowadzano z cegielni większych. Nie należy jednak o tym przesądzać.

Materiały budowlane przygotowywano przed przystąpieniem do rozplanowywania budowli. Świadczy o tym przytoczony przez Mariana Arszyńskiego przykład zamku w Grabinach, gdzie wzmianki źródłowe informują o istnieniu w 1399 r. cegielni, a w 1403 r. zaangażowaniu architekta. Wynikałoby $\mathrm{z}$ tego, że kontrakt $\mathrm{z}$ architektem podpisano po czterech latach

\footnotetext{
Ibidem, s. 48.

M. Haftka, Zamki krzyżackie w Polsce. Szkice z dziejów, Malbork 1999, s. 71.

13 A. Gardawski, Wyniki archeologicznych badań terenowych, przeprowadzonych na zamku w Działdowie w lipcu 1958 r., Warszawa 1958, s. 9-10, mps. WUOZO.
} 
przygotowywania odpowiedniej ilości materiałów budowlanych na przyszłym placu budowy ${ }^{14}$.

Z pozostałej ceramiki budowlanej należy wyróżnić także cegły glazurowane, kafle posadzkowe, a także dachówki. O pierwszych $\mathrm{z}$ nich nie można za wiele powiedzieć na tym etapie badań. Natomiast najpopularniejszym typem dachówki na terenie Prus była dachówka płaska oraz tzw. mnich-mniszka (chociaż po przejrzeniu sprawozdań z badań archeologicznych na terenie zamków Pomorza Gdańskiego oraz Warmii i Mazur wydaje mi się, że należy tę kolejność odwrócić - typ mnich-mniszka oraz dachówka płaska). Innymi materiałami do krycia dachów były gonty, słoma, trzcina, a także ołów.

Kamień stosowano głównie do budowy fundamentów oraz jako wypełniacz przy technice opus emplectum. W drugim wypadku był to na ogół miejscowy kamień polny. Jako wypełnienia używano również gruzu. Zdarzało się jednak, że stanowił on główny element budowlany murów zamku (albo przynajmniej zajmował mniej więcej połowę powierzchni muru). Wykorzystywano go również do brukowania. Kamienny bruk, który spotykamy w Działdowie, ułożony został dość regularnie na kilkucentymetrowej warstwie piasku.

W interesującej nas warowni do wykonania detali architektonicznych użyto prócz profilowanej cegły granitu i sztucznego kamienia (głównie wykorzystywanego przy wspornikach, zwornikach i filarach sklepiennych $)^{15}$.

\section{Czynności przed przystąpieniem do budowy}

Przed przystąpieniem do budowy należało dokonać rozpoznania terenu, na którym w przyszłości miała znaleźć się warownia. Przykład zamku w Grabinach świadczy o tym, że pomiędzy przeprowadzeniem wizji lokalnej a rozpoczęciem budowy gromadzono odpowiednią ilość materiałów budowlanych, jeszcze przed podpisaniem kontraktu $\mathrm{z}$ architektem. Nim przystąpiono do prac murarskich i kamieniarskich, umacniano grunt. Stosowano do tego palowanie i zakładano ruszty. W użyciu były pale dębowe i olchowe ${ }^{16}$. Zabieg ten rozpowszechnił się w średniowiecznym budownictwie europejskim. Często również podwyższano teren, na którym w późniejszym czasie miał stanąć zamek.

14 M. Arszyński, Technika i organizacja budownictwa ceglanego $w$ Prusach $w$ końcu XIV i w pierwszej połowie XV wieku, „Studia z Dziejów Rzemiosła i Przemysłu” 1970, t. 9, s. 24-25.

15 I. Galicka, Działdowo. Zamek krzyżacki, s. 33.

16 G. C. F. Lisch, Zur Geschichte des Schlosses zu Schwein, „Jahrbucher des Vereins für Mecklenburgische Geschichte und Altertumskunde" 1850, t. 15, s. 159. 


\section{Fundamentowanie}

Przy zakładaniu fundamentów należy uwzględnić wiele czynników, takich jak jakość gruntu, wielkość i rodzaj obciążenia na fundament, poziom najniższej kondygnacji budynku, poziom wód gruntowych i wiele innych ${ }^{17}$.

Wciąż otwarte pozostaje pytanie, w jakim stopniu średniowieczni budowniczowie zdawali sobie sprawę z omówionych zależności i czy brali je pod uwagę. Wydaje się jednak, że na ogół wyjątkowo trafnie dostosowywali fundament do wznoszonego budynku i nawet, pomimo że zdarzały się konstrukcje słabej jakości, okazywały się one często wystarczające. Jednak zazwyczaj fundamenty były solidniejsze niż wymagał tego budynek, co mogło wynikać z nieumiejętności wyliczenia przez budowniczych parametrów, które decydowały o sposobie fundamentowania i dlatego budowali je „na zapas". Warto o tym pamiętać przy próbach rekonstruowania naziemnych partii budynków.

Ciekawe informacje dotyczące wznoszenia fundamentów przyniosły badania wykopaliskowe w Działdowie. Wznoszenie Domu Dużego rozpoczęto od wystawienia dolnych partii kamieni fundamentu w półmetrowym wkopie wąskoprzestrzennym. Następnie rozbudowano je w górę do wysokości ok. $1 \mathrm{~m}$, po czym ów $1 \mathrm{~m}$ nadsypano piaszczystą ziemią uzyskując kolejny poziom, z którego kontynuowano wznoszenie fundamentów o kolejny metr. Tym sposobem powstał fundament zagłębiony w ziemię na $5,5 \mathrm{~m}$ oraz sztucznie usypane wzgórze zamkowe, stanowiące poziom dziedzińca dla zamku średniowiecznego. Powyżej tego poziomu rozpoczęto wznoszenie naziemnej, ceglanej partii Domu Dużego ${ }^{18}$.

Odmiennie wzniesiono na terenie tego zamku północno-wschodni mur kurtynowy, który został dostawiony do Domu Dużego. Powstał on w głębokim, oszalowanym wykopie wąskoprzestrzennym, który przeciął wzgórze zamkowe na głębokość ok. $5 \mathrm{~m}$. Najpierw wrzucono do niego kamienie polne, które następnie zalano zaprawą wapienną. Szalunek po tej operacji pozostał w wykopie ${ }^{19}$. Podobnie postąpiono w skrzydle, które z czasem zostało dostawione do owego muru, jednak z oszalowaniem wykopów fundamentowych mamy do czynienia jedynie przy podstawach dwóch filarów, które znajdowały się wewnątrz pomieszczeń przyziemia ${ }^{20}$. Fundament elewacji

\footnotetext{
Z. Mączeński, Poradnik budowlany dla architektów, Warszawa 1953, s. 20.

M. Milewska, Sprawozdanie z badań..., s. 5.

Ibidem, s. 5-6.

K. Blusiewicz, Sprawozdanie z badań..., s. 3.
} 
dziedzińca skrzydła północno-wschodniego powstał we wkopie bez szalunku, ok. 1,5 m wyżej niż posadowienie Domu Dużego ${ }^{21}$.

Zachowały się odciski po szalowaniu w zaprawie na licu fundamentów oraz smużki po drewnie ${ }^{22}$. Umożliwiało to układanie kamieni i zalewanie ich zaprawą. Dawało to mało solidny efekt. Czym wyższe partie fundamentu, tym lepsza ich jakość. W części znajdującej się pod ziemią, ale stosunkowo blisko powierzchni lico fundamentu było nieregularne, ale w układzie warstwowym z zaprawą z grubym tłuczniem, a w partiach widocznych ponad ziemią opracowane zostało regularnie, gdyż kamienie zostały dobrane wielkością i układano je płaską stroną, aby płaszczyzna lica była jednoli$\mathrm{ta}^{23}$. W najniższych partiach fundamentu skrzydła północno-wschodniego kamienie wiązano jedynie gliną, a cała konstrukcja była bardzo luźna ${ }^{24}$. Ponadto w Działdowie w nadsypanej części wzgórza, gdzie znajdowała się kwadratowa wieża, fundamentowanie musiało być dużo głębsze ze względu na niewystarczającą statyczność gruntu ${ }^{25}$.

\section{Wznoszenie murów}

To, co obecnie wiemy na temat historii technik murarskich, w głównej mierze opiera się na obserwacji powierzchni murów. Temat ten czeka od dłuższego czasu na dokładne zbadanie nie tylko przez archeologów czy historyków architektury, lecz także przez chemików czy historyków techniki.

W budownictwie krzyżackim w pierwszej kolejności wznoszono na ogół mury magistralne ${ }^{26}$. Przed przystąpieniem do rozbudowy dla doraźnych potrzeb budowano obiekty drewniane lub ryglowe. Zanim przystępowano do prac nad sklepianiem wnętrz, najczęściej kryto budowlę dachem. Budowa sklepień stanowiła zazwyczaj ostatni etap prac murarskich. Łuki i wysklepki powstawały na krążynach i szalowaniach. Po zbudowaniu sklepień obciążano je ziemią, a następnie ich wierzch pokrywano polepą ${ }^{27}$.

Tempo robót murarskich zależało od technologii. Zaprawa wapienna wiązała się powoli. Starano się przyspieszyć ten proces poprzez różne sposoby,

$21 \quad$ M. Milewska, Sprawozdanie z badań..., s. 7.

22 A. Gardawski, Wyniki..., s. 3; K. Blusiewicz, Sprawozdanie z badań.., s. 3.

23 I. Galicka, Działdowo. Zamek krzyżacki, s. 33.

24 K. Blusiewicz, Sprawozdanie z badań..., s. 3.

25 A. Gardawski, Wyniki..., s. 8.

26 M. Arszyński, Technika i organizacja..., s. 114.

27 Ibidem, s. 115-116. 
jak np. wkładanie do muru drewnianych żerdzi, które po czasie wyciągano. Tworzono w ten sposób otwory, które doprowadzały do wnętrza muru powietrze, powodując szybsze zastyganie zaprawy ${ }^{28}$.

\section{Drewno na zamku}

W powszechnym wyobrażeniu zamki krzyżackie uchodzą za całkowicie murowane, drewno było w nich jednak powszechnie stosowane. W zamkach murowanych powstawały drewniane urządzenia oparte na murach obronnych, takie jak ganki czy hurydycje. W źródłach często wymieniane są również różnego rodzaju parkany, komory, sionki, domy itp. Część z nich wznoszona była $z$ drewna, a zagęszczenie tego typu obiektów na terenie zamku było zazwyczaj znaczne. Zwykle większość urządzeń komunikacyjnych również wykonana była $\mathrm{z}$ drewna (istnieją wyjątki, jak np. murowane krużganki w Malborku lub w biskupim Lidzbarku Warmińskim).

$\mathrm{O}$ istnieniu drewnianych krużganków informują nas najczęściej otwory w murach, pozostałe po mocowaniach tych konstrukcji. O istnieniu takiej formy komunikacji możemy mówić w wypadku kilku założeń - niektóre z nich (np. w Bytowie) zostały częściowo zrekonstruowane. W Nidzicy, niestety, ich rekonstrukcja budzi liczne kontrowersje (obecnie są betonowe). Wyraźnie widoczne w elewacji zamku w Działdowie są gniazda po belkach poziomych i zastrzałach. Ganki były tam częściowo nadwieszone.

\section{Zakończenie}

Praca Mariana Arszyńskiego o budownictwie murowanym w Prusach ${ }^{29}$ okazała się przełomowa i jest cytowana do dnia dzisiejszego. Tomasz Torbus pisząc swoją pracę doktorską, która nie tak dawno ukazała się w polskim tłumaczeniu, również zaznaczył $w$ rozdziale dotyczącym organizacji budowy, że w głównej mierze powtarza wnioski z pracy Arszyńskiego ${ }^{30}$. Wydaje się, że wykorzystał on w znacznej części możliwości, które dają nam źródła pisane do poznania tego zagadnienia. Dlatego tak ważne wydaje się sięgnięcie po źródła archeologiczne, które te informacje znakomicie uzupełniają. Zdecydowałem się dodać do części wniosków podawanych przez

28 M. Haftka, Zamki krzyżackie. Przezmark - Dzierzgoń - Sztum, Gdańsk 2010, s. 160.

29 M. Arszyński, Technika i organizacja...

30 T. Torbus, Zamki konwentualne państwa krzyżackiego w Prusach, Gdańsk 2014, s. 367. 
M. Arszyńskiego obserwacje, które zostały poczynione podczas badań archeologicznych w Działdowie. Okazało się to o tyle ciekawe, że znakomicie poszerza pracę tego badacza, a jednocześnie przybliża wyniki badań prowadzonych na terenie zamku, które nie zostały dotychczas opublikowane.

\section{Bibliografia}

ARSZYŃSKI M., Technika i organizacja budownictwa ceglanego $w$ Prusach $w$ końcu XIV i w pierwszej połowie XV w., „Studia z Dziejów Rzemiosła i Przemysłu” 1970, t. 9.

BLUSIEWICZ K., Sprawozdanie z badań archeologicznych przeprowadzonych na zamku w Działdowie w 2008 r., mps. WUOZO.

GALICKA I., Działdowo. Zamek krzyżacki, Warszawa 1958/1959, mps. WUOZO.

GALICKI W., Działdowo. Zamek krzyżacki. Badania architektoniczne, Warszawa 1958/1959, mps. WUOZO.

GARDAWSKI A., Wyniki archeologicznych badań terenowych, przeprowadzonych na zamku w Działdowie w lipcu 1958 r., Warszawa 1958, s. 9-10, mps. WUOZO.

HAFTKA M., Zamki krzyżackie. Przezmark - Dzierzgoń - Sztum, Gdańsk 2010. HAFTKA M., Zamki krzyżackie w Polsce. Szkice z dziejów, Malbork 1999.

MILEWSKA M., Sprawozdanie z badań archeologicznych prowadzonych na zamku w Działdowie w latach 1981-1989, Warszawa 1990, mps. WUOZO.

LISCH G. C. F., Zur Geschichte des Schlosses zu Schwein, „Jahrbucher des Vereins für Mecklenburgische Geschichte und Altertumskunde" 1850, t. 15.

MĄCZEŃSKI Z., Poradnik budowlany dla architektów, Warszawa 1953.

TORBUS T., Zamki konwentualne państwa krzyżackiego w Prusach, Gdańsk 2014. 